\title{
ANALISIS PERBANDINGAN BEBAN PAJAK PENGHASILAN TERHUTANG MENURUT PASAL 31E UNDANG UNDANG PAJAK PENGHASILAN DENGAN PERATURAN PEMERINTAH NOMOR 46 TAHUN 2013 PADA PT ABC
}

\author{
P. Helen Widjaja dan Jason Pratama \\ Fakultas Ekonomi Universitas Tarumanagara \\ Email: helenpww@gmail.com
}

\begin{abstract}
This case study analyzed by comparing the income tax payable according to Article 31E of the Income Tax Law and Government Regulation No. 46 Year 2013 on PT ABC. In the results of this study prove that according to Government Regulation No. 46 Year 2013 resulted in income tax payable is less than pursuant to Article 31e Income Tax Act .
\end{abstract}

Keywords: Corporate Income Tax payable, Article 31E of Income Tax Law, Government Regulation No. 46 Year 2013

\begin{abstract}
Abstrak: Studi kasus ini menganalisa dengan membandingkan beban pajak penghasilan terhutang menurut Pasal 31E Undang Undang Pajak Penghasilan dengan Peraturan Pemerintah Nomor 46 Tahun 2013 pada PT. ABC. Dalam hasil penelitian ini membuktikan bahwa menurut Peraturan Pemerintah Nomor 46 Tahun 2013 menghasilkan beban pajak penghasilan terhutang lebih kecil dibandingkan menurut Pasal 31E Undang Undang Pajak Penghasilan.
\end{abstract}

Kata Kunci: PPh Badan terutang, Pasal 31 E Undang-undang Pajak Penghasilan, Peraturan Pemerintah Nomor 46 tahun 2013

\section{PENDAHULUAN}

Pajak merupakan salah satu sumber penerimaan Pemerintah Republik Indonesia yang sangat potensial.Sebagai salah satu sumber penerimaan Pemerintah, pajak dapat dipergunakan untuk membiayai kegiatan Pemerintah (budgeter), maupun untuk meningkatkan kegiatan masyarakat.Alokasi pajak untuk pembangunan prasarana, dan perbaikan kualitas sumber daya manusia berpengaruh positif terhadap kegiatan ekonomi masyarakat. Di Indonesia, jenis pajak dapat dikelompokan menurut golongan, sifat dan lembaga pemungutnya. Jenis pajak menurut golongannya dibagi menjadi dua, yaitu: 1) Pajak Langsung, dan 2) Pajak Tidak Langsung. Menurut sifatnya, yaitu: 1) Pajak Subyektif, dan 2) Pajak Objektif. Menurut pemungutnya, yaitu: 1) Pajak Pusat, dan 2) Pajak Daerah. Pajak Pusat (Negara) merupakan pajak yang dipungut oleh pemerintah pusat dan digunakan untuk membiayai pengeluaran negara. Adapun contoh dari pajak Pusat yaitu: Pajak Penghasilan (PPh), Pajak Pertambahan Nilai (PPN), Pajak Penjualan Barang Mewah (PPnBM), bea materai, Pajak Bumi dan Bangunan (PBB), serta Bea Perolehan Hak Atas Tanah dan Bangunan (BPHTB).

Pajak penghasilan adalah pajak yang dikenakan kepada Subjek Pajak atas penghasilan yang diterima dalam satu tahun pajak.Subjek Pajak yang dimaksud adalah baik orang pribadi maupun badan (perusahaan). Penghasilan suatu perusahaan akan dihitung dari catatan, buku, serta dokumen pendukung lainnya yang dikelola dalam suatu 
sistem akuntansi yang dilakukan oleh perusahaan. Dari penghasilan perusahaan inilah yang akan dikenakan tarif pajak penghasilan. Pajak penghasilan merupakan bagian dari laba bersih perusahaan.Bagi pemerintah, pajak mempunyai fungsi sebagai sumber penerimaan negara.Berdasarkan fungsi ini, pajak adalah bagian laba perusahaan yang seharusnya diberikan ke pemerintah untuk mendukung pembangunan nasional. Hal ini mengakibatkan semakin besar pajak yang disetorkan oleh perusahaan maka akan semakin baik bagi pemerintah. Di sisi yang lain, bagi perusahaan pajak lebih sering dianggap sebagai pos pengurang laba bersih yang seharusnya bisa diminimalkan oleh perusahaan. Pajak diakui sebagai elemen utama dalam kebijakan pengeluaran perusahaan dan bagi perusahaan, pajak penghasilan adalah bagian laba bersih yang dibagikan ke pihak lain (pemerintah), sehingga pajak akan mengurangi bagian laba yang seharusnya dapat dibagikan ke pihak manajemen, pemilik modal atau dimanfaatkan untuk peningkatan investasi perusahaan.

Seiring dengan berjalannya waktu masih banyak para pelaku UMKM yang belum mengerti dengan perhitungan pajaknya, sehingga pemerintah menerbitkan regulasi tentang Pajak Penghasilan bagi UMKM tertanggal 12 Juni 2013 yaitu Peraturan Pemerintah (PP) Nomor 46 Tahun 2013 (PPh 46). Apabila diperhatikan dengan seksama, kriteria Wajib Pajak UMKM sebagaimana diatur dalam PPh Pasal 31E dan PP 46 Tahun 2013 terdapat irisan penerapan kriteria Wajib Pajak yang mendapat fasilitas. Irisan kriteria yang dimaksudkan adalah Wajib Pajak yang memiliki peredaran bruto Rp4.800.000.000,00 dalam satu tahun pajak. Berdasarkan Undang-Undang PPh Pasal 31E Wajib Pajak yang memiliki peredaran bruto dibawah Rp4.800.000.000,00 akan mendapatkan diskon tarif $50 \%$ dari tarif PPh badan yang sebagaimana dimaksudkan dalam Pasal 17 ayat (1) huruf b dan atau (2a) UU PPh dan tidak bersifat final. Sedangkan menurut PP 46 Tahun 2013 Wajib Pajak badan yang memiliki peredaran bruto dibawah Rp4.800.000.000,00 akan dikenakan tarif sebesar $1 \%$ dari omzet dan bersifat final.Pembahasan studi kasus ini ingin mengetahui perhitungan menurut manakah yang lebih meringankan beban pajak penghasilan terhutang pada PT. ABC

\section{KAJIAN TEORI}

Pajak (dari bahasa Latin taxo; "rate") adalah iuran rakyat kepada negara berdasarkan undang-undang, sehingga dapat dipaksakan, dengan tidak mendapat balas jasa secara langsung.Pajak dipungut berdasarkan norma-norma hukum untuk menutup biaya produksi barang dan jasa kolektif untuk mencapai kesejahteraan umum. Definisi pajak yang dikemukakan oleh Prof. Dr. Rochmat Soemitro, S.H. (Resmi, 2014:1):

"Pajak adalah iuran rakyat kepada kas Negara berdasarkan undang-undang (yang dapat dipaksakan) dengan tidak mendapat jasa timbale balik (kontraprestasi) yang langsung dapat ditunjukkan, dan yang digunakan untuk membayar pengeluaran umum."

Definisi tersebut disempurnakan, menjadi:

"Pajak adalah peralihan kekayaan dari pihak rakyat kepada kas Negara untuk membiayai pengeluaran rutin dan "surplus"-nya digunakan untuk public saving yang merupakan sumber utama untuk membiayai public investment."

Pengertian Pajak Penghasilan (PPh). Pajak penghasilan (PPh) adalah pajak yang dikenakan terhadap Subjek Pajak Penghasilan atas Penghasilan yang diterima atau diperolehnya dalam tahun pajak. Subjek pajak tersebut dikenai pajak apabila 
menerima atau memperoleh penghasilan. Subjek pajak yang menerima atau memperoleh penghasilan, dalam Undang-Undang No. 36 tahun 2008 tentang Pajak Penghasilan (PPh) disebut Wajib Pajak. Wajib Pajak dikenai pajak atas penghasilan yang diterima atau diperolehnya selama satu tahun pajak atau dapat pula dikenai pajak untuk penghasilan dalam bagian tahun pajak apabila kewajiban pajak subjektifnya dimulai atau berakhir dalam tahun pajak.

Pajak Penghasilan merupakan jenis pajak subjektif yang kewajiban pajaknya melekat pada Subjek Pajak yang bersangkutan, artinya kewajiban pajak tersebut dimaksudkan untuk tidak dilimpahkan kepada Subjek Pajak lainnya.Oleh karena itu dalam rangka memberikan kepastian hukum, penentuan saat mulai dan berakhirnya kewajiban pajak subjektif menjadi penting.

Subjek Pajak Penghasilan. Berdasarkan Pasal 2 ayat 1 UU No. 36 Tahun 2008, Subjek Pajak dikelompokkan sebagai berikut:

1. Orang Pribadi. Orang pribadi sebagai subjek pajak dapat bertempat tinggal atau berada di Indonesia ataupun di luar Indonesia.Pengertian orang pribadi menurut Rochmat Soemitro adalah manusia dari daging, tulang, dan darah.

2. Subjek Pajak Warisan belum terbagi sebagai satu kesatuan menggantikan yang berhak. Warisan yang belum terbagi sebagai satu kesatuan merupakan subjek pajak pengganti, menggantikan mereka yang berhak yaitu ahli waris, maksud warisan disini adalah warisan yang menghasilkan atau masih ada pajak terutang yang ditinggalkan. Dalam menjalankan kewajiban perpajakannya, warisan yang belum terbagi bisa diwakili oleh: (a) Salah seorang ahli warisnya;(b) Pelaksana wasiatnya; (c) Pihak yang mengurus harta peninggalannya.

3. Badan. Badan adalah sekumpulan orang dan/atau modal yang merupakan kesatuan baik yang melakukan usaha maupun yang tidak melakukan usaha yang meliputi perseroan terbatas, perseroan komanditer, perseroan lainnya, badan usaha milik negara atau badan usaha milik daerah dengan nama dan dalam bentuk apa pun, firma, kongsi, koperasi, dana pensiun, persekutuan, perkumpulan, yayasan, organisasi massa, organisasi sosial politik, atau organisasi lainnya, lembaga, dan bentuk badan lainnya termasuk kontrak investasi kolektif dan bentuk usaha tetap.

4. Bentuk Usaha Tetap (BUT). Bentuk Usaha Tetap adalah bentuk usaha yang dipergunakan oleh orang pribadi yang tidak bertempat tinggal di Indonesia atau berada di Indonesia tidak lebih dari 183 (seratus delapan puluh tiga) hari dalam jangka waktu 12 (dua belas) bulan, atau badan yang tidak didirikan dan tidak bertempat kedudukan di Indonesia, untuk menjalankan usaha dan melakukan kegiatan di Indonesia.

Subjek Pajak bisa terdiri dari: (1) Subjek Pajak Dalam Negeri dan (2) Subjek Pajak Luar Negeri.Untuk kedua Subjek Pajak ini terdapat perbedaaan atas kewajiban perpajakannya. Perbedaan tersebut antara lain:

1. Ruang lingkup penghasilan yang dapat dikenakan pajak. Subjek Pajak Dalam Negeri: Penghasilan yg diterima atau diperoleh dari Indonesia maupun dari Luar Indonesia (World Wide Income). Subjek Pajak Luar Negeri: Penghasilan yang berasal dari Indonesia saja (asal sumber penghasilan di Indonesia)

2. Dasar Pengenaan Pajak. Subjek Pajak Dalam Negeri: Dikenakan pph berdasarkan penghasilan netto (Penghasilan Kena Pajak) dengan tarif umum

Subjek Pajak Luar Negeri: Dikenakan pajak berdasarkan penghasilan bruto dengan tarif sepadan 
3. Tarif Pajak. Subjek Pajak Dalam Negeri: (a) Tarif Umum PPh (pasal 17) yaitu:

Tarif tunggal 28\%; (ii) WP Badan. - 5\%, 15\%, 25\%, dan 30\% WP OP, (b) Dikenakan Tarif PPh. Final (Psl 4 ayat 2)

Subjek Pajak Luar Negeri: Tarif Sepadan PPh (Pasal 26) atau sesuai dengan taxtreaty yaitu: dikenakan tariff khusus Pasal 16 atau sesuai dengan tariff menurut P3B (TaxTreaty)

4. Kewajiban memiliki NPWP. Subjek Pajak Dalam Negeri: wajib, Subjek Pajak Luar Negeri: tidak wajib

5. Kewajiban Penyampaian SPT, Subjek Pajak Dalam Negeri : Wajib menyampaikan SPT Masa maupun Tahunan. Subjek Pajak Luar Negeri: Tidak wajib menyampaikan SPT Masa maupun Tahunan

6. Pembayaran Pajak Tahun Berjalan, Subjek Pajak Dalam Negeri: Merupakan angsuran dari PPh yang terutang pada akhir tahun, kecuali yang Final

Subjek Pajak Luar Negeri: Merupakan pembayaran yang Final kecuali yang berubah status

7. Subjek Pajak Orang Pribadi, Subjek Pajak Dalam Negeri: Dapat pengurangan beban PTKP. SPLN: Tidak dapat pengurang PTKP.

8. Keberatan dan Banding, Subjek Pajak Dalam Negeri: Mempunyai Hak.Subjek Pajak Luar Negeri: Tidak mempunyai hak

9. Pembukuan dan Pencatatan. Subjek Pajak Dalam Negeri: Diwajibkan menyelenggarakan; Subjek Pajak Luar Negeri: Tidak terdapat kewajiban

Pajak Penghasilan Pasal 31E Tahun 2008. Dasar Hukum: (1) Pasal 31E UU No. 36 Tahun 2008 tentang Pajak Penghasilan; (2) Surat Edaran DJP No: SE.66/PJ/2010 tentang Penegasan atas Pelaksanaan Pasal 31E Ayat (1) UU No.36 Tahun 2008 tentang Pajak Penghasilan.

Pajak Penghasilan Pasal 31E dimunculkan dalam UU No. 36 tahun 2008. Pasal 31E ayat (1) UU PPh diatur bahwa Wajib Pajak dalam negeri dengan peredaran bruto sampai dengan Rp. 50.000.000.000,00 (lima puluh milyar rupiah) mendapat fasilitas berupa pengurangan tariff sebesar 50\% (lima puluh persen) dari tariff normal 28\% (tahun 2009) dan 25\% (tahun 2010-skrg) yang dikenakan atas Penghasilan Kena Pajak dari bagian peredaran bruto sampai dengan Rp. 4.800.000.000 (empat milyar delapan ratus juta rupiah).

Sejak diterbitkan pada tanggal 23 September 2008, penjelasan mengenai aturan ini belum jelas dan tidak ada peraturan yang mengatur lebih lanjut. Namun per tanggal 24 Mei 2010 dterbitkan Surat Edaran Dirjen Pajak No. 66/PJ/2010 yang menjelaskan mengenai:

1. Fasilitas pengurangan tariff sesuai dengan Pasal 31E ayat (1) UU PPh dilaksanakan dengan caraSelf Assessmentpada saat penyampaian Surat Pemberitahuan Tahunan Pajak Penghasilan Wajib Pajak Badan. Dengan demikian, Wajib Pajak tidak perlu menyampaikan permohonan untuk dapat memperoleh fasilitas tersebut.

2. Batasan peredaran bruto sampai dengan Rp. 50.000.000.000,00 adalah sebagai batasan maksimal peredaran bruto yang diterima atau diperoleh Wajib Pajak Badan dalam negeri untuk dapat memperoleh fasilitas pengurangan tariff sesuai dengan Pasal 31E ayat (1) UU PPh.

3. Peredaran Bruto sebagaimana yang dimaksud dalam Pasal 31E ayat (1) UU PPh adalah penghasilan yang diterima atau diperoleh dari kegiatan usaha sebelum dikurangi biaya untuk mendapatkan, menagih, dan memelihara penghasilan baik yang berasal dari 
Indonesia maupun di luar Indonesia, meliput: (a) Penghasilan yang dikenai Pajak Penghasilan bersifat final; (b) Penghasilan yang dikenai Pajak Penghasilan tidak bersifat final; (c) Penghasilan yang dikecualikan dari objek pajak.

4. Dalam Surat Edaran Dirjen Pajak tersebut ditegaskan juga bahwa fasilitas Pasal 31E ayat (1) tersebut bukan merupakan pilihan, sehingga dapat dianalogikan bahwa merupakan kewajiban bagi WPDN yang penghasilan brutonya dibawah atau sampai dengan lima puluh milyar rupiah.

Wajib Pajak Badan yang berhak menggunakan fasilitas ini yaitu Wajib Pajak Badan dalam negeri dan Bentuk Usaha Tetap yang memperoleh peredaran bruto hingga Rp50.000.000.000,00 (Lima puluh miliar rupiah) dengan penghasilan kena pajak didalam peredaran bruto hingga Rp4.800.000.000,00 (Empat miliar delapan ratus juta rupiah).

Peredaran bruto yang dimaksud adalah penghasilan yang diperoleh dari usaha dan di luar usaha (penghasilan lain - lain).Sedangkan Penghasilan Kena Pajak yang dimaksud adalah penghasilan bersih setelah dilakukan koreksi fiskal (menyesuaikan pendapatan dan beban yang diperbolehkan untuk menghitung penghasilan bersih menurut peraturan perpajakan).

Peraturan Pemerintah Nomor 46 Tahun 2013. Menurut Ratna Anjarwati (2014:50), Subjek pajak dari Peraturan Pemerintah nomor 46 Tahun 2013 adalah semua Wajib Pajak, baik perorangan maupun badan kecuali bentuk usaha tetap (BUT) dengan peredaran bruto yang memenuhi kriteria berikut yaitu Wajib Pajak yang menerima penghasilan dari usaha tidak termasuk penghasilan dari jasa sehubungan dengan pekerjaan bebas dengan peredaran bruto tidak melebihi Rp. 4.800.000.000,00 (4.8 M) dalam 1 tahun fiskal. Latar belakang dikeluarkannya Peraturan Pemerintah No. 46 tahun 2013 adalah karena masih rendahnya penerimaan pajak dari sektor UMKM, nol koma tujuh persen $(0,7 \%)$ sedangkan kontribusinya ke perekonomian Indonesia sangat besar yakni limapuluh tujuh koma Sembilan puluh empat persen (57,94\%). Berdasarkan data Badan Pusat Statistik (BPS), jumlah UMKM berkisar diangka enak puluh juta (60 juta).Pengertian UMKM menurut Undang-undang (UU) No. 20 Tahun 2008 tentang Usaha Mikro, Kecil dan Menengah, yakni usaha yang dilakukan orang perorangan atau badan usaha dengan peredaran maksimum Rp50 miliar dalam setahun.

Peraturan Pemerintah No. 46 melaksanakan ketentuan pengenaan $\mathrm{PPh}$ sebesar 1\% dari peredaran bruto bagi wajib pajak yang memiliki peredaran bruto yang tidak melebihi dari 4,8 Milyar rupiah dalam jangka waktu satu tahun.Penghasilan yang dikenai PPh Final sebesar 1\% berdasarkan PP Nomor 46 Tahun 2013 adalah penghasilan yang diterima atau diperoleh dari kegiatan usaha, kecuali: (1) Penghasilan yang diterima atau diperoleh dari jasa sehubungan pekerjaan bebas sebagaimana dimaksud dalam PP 46 Tahun 2013, (2) Penghasilan yang diterima atau diperoleh di luar negeri,(3) Penghasilan yang telah dikenai $\mathrm{PPh}$ yang bersifat final dengan ketentuan peraturan perundang-undangan perpajakan tersendiri; dan (4) Penghasilan yang dikecualikan sebagai objek pajak.

Penentuan saat beroperasi secara komersial bagi Wajib Pajak badan adalah saat Wajib Pajak melakukan kegiatan operasi secara komersial untuk pertama kali. Bagi Wajib Pajak yang bergerak di sektor: (1) Jasa, adalah saat pertama kali dilakukannya penjualan jasa dan/atau saat diterima atau diperolehnya pendapatan/penghasilan; dan/atau (2) Dagang dan industri, adalah saat pertama kali dilakukannya penjualan barang dan/atau saat diterima atau diperolehnya pendapatan/penghasilan.

Penentuan peredaran bruto untuk dikenakan PPh Final berdasarkan PP Nomor 46 Tahun 2013 bagi Wajib Pajak badan yang baru beroperasi secara komersial untuk 
pertama kali, ditentukan berdasarkan peredaran bruto dari usaha dalam 1 (satu) Tahun Pajak setelah Tahun Pajak beroperasi secara komersial. Wajib Pajak badan yang baru beroperasi secara komersial sebagaimana disebutkan di atas, dikenai PPh berdasarkan tarif umum UU PPh sampai dengan jangka waktu 1 (satu) tahun sejak beroperasi secara komersial. Dalam hal jangka waktu 1 (satu) tahun sejak beroperasi secara komersial ini melewati Tahun Pajak saat beroperasi secara komersial, ketentuan pengenaan $\mathrm{PPh}$ berdasarkan tarif umum UU PPh berlaku sampai dengan akhir Tahun Pajak berikutnya setelah Tahun Pajak saat beroperasi secara komersial.

Pengenaan PPh yang bersifat final berdasarkan PP 46 Tahun 2013 bagi Wajib Pajak badan yang baru beroperasi secara komersial untuk pertama kali, untuk tahun selanjutnya ditentukan berdasarkan peredaran bruto Tahun Pajak sebelumnya.

Ketentuan Penyetoran dan Pelaporan SPT Masa PPh Pasal 4 ayat (2) Sesuai Ketentuan PP 46 Tahun 2013

a. Ketentuan Penyetoran PPh. Wajib Pajak wajib menyetorkan PPh terutang ke kas negara melalui: (i) Kantor pos atau bank yang ditunjuk oleh Menteri Keuangan dengan menggunakan SSP; (ii) Anjungan Tunai Mandiri (ATM) bank-bank tertentu dimana Wajib Pajak menerima Bukti Penerimaan Negara (BPN) dengan teraan Nomor Transaksi Penerimaa Negara (NTPN) dalam bentuk cetakan struk ATM yang kedudukannya disamakan dengan SSP, paling lambat tanggal 15 bulan berikutnya setelah Masa Pajak berakhir.

b. Ketentuan Pelaporan SPT Masa. Wajib Pajak yang melakukan pembayaran Pajak Penghasilan sebagaimana dimaksud pada huruf a wajib menyampaikan SPT Masa PPh paling lama 20 hari setelah Masa Pajak berakhir.

Wajib Pajak yang telah melakukan penyetoran $\mathrm{PPh}$ final 1\% dan telah mendapatkan validasi NTPN, dianggap telah menyampaikan/melaporkan SPT Masa PPh, dengan tanggal pelaporan sesuai tanggal NTPN yang tercantum pada SSP atau cetakan struk ATM.

\section{METODE}

Penelitian ini dilakukan dengan objek penelitian Perseroan Terbatas (PT) ABC.PT. ABC yang terletak di Jalan Kramat Raya XXX Nomor XX Jakarta Pusat.Perusahaan ini didirikan pada tanggal 15 Juni 2010. PT. ABC bergerak dalam bidang pengecatan kapal, gedung, eksterior, interior, flooring dan water proffing. Proyek yang sudah dikerjakan oleh PT. ABC antara lain di Plaza Indonesia, Pacific Palace, Matahari Cisarua Bogor, Snow Bay TMII. dan ITC Kuningan dan Mall Ambassador. Saat ini PT. ABC sedang mengembangkan usaha lain dalam bidang pengolahan tambang yaitu partikel logam.

Pendekatan dalam penelitian ini termasuk kedalam pendekatan kuantitatif, yaitu dengan teknik pengolahan data , dimana dengan data tersebut dilakukan klasifikasi, dihitung, dan dibandingkan dengan rumus rumus atau peraturan perhitungan pajak yang berlaku dan relevan.

Dalam penelitian ini, pengumpulan data dilakukan dengan cara penelitian lapangan yaitu wawancara baik wawancara terstruktur dan wawancara tidak terstruktur dan observasi. Selain penelitian lapangan, pengumpulan data juga dilakukan dengan studi kepustakaann yaitu data sekunder dari berbagai buku, dokumen, artikel, dll yang berkaitan dengan penelitian ini.

Setelah mendapatkan seluruh data yang dibutuhkan, selanjutnya dilakukan analisis 
data atau pengolahan data yang dilakukan dengan 3 langkah, yaitu pertama meng-edit / editing. Kedua dengan tabulasi dan terakhir adalah analisis data itu sendiri untuk dapat diperoleh kesimpulan atas seluruh penelitian ini.

\section{HASIL DAN PEMBAHASAN}

Tabel 1. PT ABC

LAPORAN LABA (RUGI) SERTA PERHITUNGAN PPH TERHUTANG BERDASARKAN PERATURAN PEMERINTAH NOMOR 46 TAHUN 2013 TAHUN 2014

\begin{tabular}{|c|c|c|}
\hline PENJUALAN & & 859.489 .227 \\
\hline \multicolumn{3}{|l|}{ HARGA POKOK PENDAPATAN } \\
\hline $\begin{array}{l}\text { Persediaan Awal } \\
\text { Pembelian } \\
\text { Persediaan Untuk Dijual } \\
\text { Persediaan Akhir }\end{array}$ & $\begin{array}{r}115.111 .000 \\
207.620 .637 \\
360.072 .250 \\
(54.042 .500) \\
\end{array}$ & 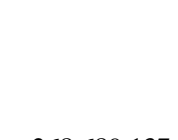 \\
\hline Total Harga Pokok Pendapatan & & $\underline{268.689 .137}$ \\
\hline LABA (RUGI) KOTOR & & 590.800 .090 \\
\hline \multicolumn{3}{|l|}{ BEBAN USAHA } \\
\hline $\begin{array}{l}\text { Biaya Gaji Karyawan \& THR } \\
\text { Biasa Telepon, Listrik dan Air } \\
\text { Biaya Transportasi } \\
\text { Biaya Perlengkapan Kantor } \\
\text { Biaya Operasional Kantor } \\
\text { Biaya Adm. \& Umum Kantor } \\
\text { Biaya PPH } 4 \text { (2) PP } 46 \\
\text { Biaya Adm. Bank } \\
\text { Biaya Penyusutan Kendaraan } \\
\quad \text { Total Beban Usaha }\end{array}$ & $\begin{array}{r}268.500 .000 \\
7.070 .189 \\
7.609 .304 \\
75.166 .544 \\
51.927 .585 \\
57.606 .500 \\
8.594 .894 \\
1.157 .500 \\
22.187 .500 \\
\end{array}$ & \\
\hline \multicolumn{3}{|l|}{ PENDAPATAN \& BEBAN LAINNYA } \\
\hline $\begin{array}{l}\text { Jasa Giro } \\
\text { Pajak Jasa Giro } \\
\quad \text { Total Pendapatan Lainnya }\end{array}$ & $\begin{array}{r}27.430 \\
(3.338) \\
\end{array}$ & 24.092 \\
\hline LABA BERSIH USAHA & & $\underline{91.004 .166}$ \\
\hline \multicolumn{3}{|l|}{ KOREKSI FISKAL POSITIF } \\
\hline \multicolumn{3}{|l|}{ Pendapatan Yang Dikenakan PPH Final } \\
\hline Pajak Bunga Bank & & \\
\hline $\begin{array}{l}\text { Harga Pokok Pendapatan Yang Dikenakan PPH } \\
\text { Final }\end{array}$ & $\underline{268.689 .137}$ & \\
\hline TOTAL KOREKSI FISKAL POSITIF & & 768.512 .491 \\
\hline KOREKSI FISKAL NEGATIF & (859.489.227) & \\
\hline $\begin{array}{l}\text { Jasa Giro } \\
\text { TOTAL KOREKSI FISKAL NEGATIF } \\
\text { Penghasilan Kena Pajak }\end{array}$ & $\underline{(27.430)}$ & \\
\hline & & (859.516.657) \\
\hline
\end{tabular}


Dalam penelitian ini, dilakukan analisis terhadap PT ABC dengan membandingkan beban pajak penghasilannya apabila Perusahaan menggunakan perhitungan pajak penghasilan berdasarkan pasal 31E Undang-Undang PPh tahun 2008 dengan Peraturan Pemerintah Nomor 46 tahun 2013.Dimana akan dianalisis dalam penelitian ini perhitungan manakah yang akan lebih meringankan beban pajak penghasilan terhadap PT. ABC untuk Tahun 2014 dan Tahun 2015.

Berdasarkan Tabel 1 diatas, perusahaan PT ABC memiliki total penjualan untuk tahun pajak 2014 sebesar Rp 859.489.227,00. Dan dapat dilihat pada tersebut PT ABC menggunakan Peraturan Pemerintah Nomor 46 dalam perhitungan pajak penghasilannya karena penjualan (omzet) untuk tahun pajak 2014 dibawah 4,8 milyar rupiah $(<4,8 \mathrm{M})$.

Pajak Terhutang = Omzet $\times 1 \%$

Pajak Terhutang = Rp. 859.489.227 x $1 \%$

Pajak Terhutang = Rp. 8.594.894

Dari perhitungan diatas, maka total besarnya pajak terhutang untuk PT.ABC Tahun pajak 2014 menurut Peraturan Pemerintah Nomor 46 tahun 2013 adalah sebesar Rp. 8.594.894,00 
Tabel 2. PTABC

LAPORAN LABA (RUGI) SERTA PERHITUNGAN PPH TERHUTANG

BERDASARKAN PAJAK PENGHASILAN PASAL 31E

TAHUN 2014

PENJUALAN

HARGA POKOK PENDAPATAN

Persediaan Awal

Pembelian

Persediaan Untuk Dijual

Persediaan Akhir

KOREKSI FISKAL POSITIF

Berdasarkan Tabel 2 diatas, perusahaan tidak menggunakan perhitungan pajak penghasilan berdasarkan Peraturan Pemerintah Nomor 46 Tahun 2013, dan menghasilkan laba setelah koreksi fiskal sebesar Rp 99.574.968,00.

Untuk menghitung PPh Badan dengan Fasilitas Pasal 31E, dapat menggunakan rumus sebagai berikut (hanya untuk wajib pajak badan yangpenghasilan kena pajaknya dibawah 4,8 Miliar dalam periode 1 tahun): 
$50 \%$ x 25\% x Penghasilan Kena Pajak yang memperoleh fasilitas = PPh Badan dengan fasilitas terutang.

Perhitungan PPh Badan terutang untuk tahun pajak 2014 berdasarkan Pasal 31 E UU PPh adalah sebagai berikut :

$$
50 \% \text { x } 25 \% \text { x Rp. } 99.574 .000=\text { Rp. } 12.446 .750,00
$$

Dari perhitungan diatas, Jika PT.ABC menggunakan perhitungan pajak penghasilan menggunakan pasal 31E UU PPh tahun 2013 maka besarnya PPh Terhutang untuk tahun pajak 2014 adalah sebesar Rp12.446.750,00.

Perbandingan Beban Pajak Terhutang PP 46 dan Pasal 31E Tahun Pajak 2014

Dasar Perhitungan

Jumlah

Peraturan Pemerintah Nomor 46 Tahun

2013

Pajak Penghasilan Pasal 31E Nomor 36

Rp. 8.594.894,00

Tahun 2008

Rp. $12.446 .750,00$

Berdasarkan perhitungan diatas dapat diketahui bahwa besarnya pajak yang diterapkan dengan menggunakan Peraturan Pemerintah No. 46 akan memberikan dampak yang menguntungkan bagi perusahaan karena memiliki beban pajak penghasilan yang lebih kecil apabila dibandingkan dengan menggunakan perhitungan Pajak Penghasilan Pasal 31E Nomor 36 UU PPh tahun 2008

Tabel 3. PTABC

LAPORAN LABA (RUGI) SERTA PERHITUNGAN PPH TERHUTANG BERDASARKAN PERATURAN PEMERINTAH NOMOR 46 TAHUN 2013 TAHUN 2015

Dalam Rupiah 


\section{HARGA POKOK PENDAPATAN}

Persediaan Awal

Pembelian

Persediaan Untuk Dijual

Persediaan Akhir

Total Harga Pokok Penjualan

LABA (RUGI) KOTOR

\section{BEBAN USAHA}

Biaya Gaji Karyawan

Biasa Listrik

Biaya Air

Biaya Telepon dan Internet

Biaya Transportasi

Biaya Adm. \& Umum Kantor

Biaya Penyusutan Kendaraan

Biaya Keperluan Kantor

Biaya Operasional

Biaya PPh 23

Biaya PP 46

Total Beban Usaha
54.042 .500

$\underline{537.425 .000}$

591.467 .500

$\underline{(107.488 .000)}$

$\underline{483.982 .500}$

829.856 .393

283.500.000

3.600 .000

1.767 .500

1.833.677

87.629 .100

107.881 .800

22.187 .500

83.399 .600

112.891 .400

16.099 .378

$\underline{13.138 .389}$

$\underline{(733.928 .344)}$

\subsection{3 .900}

LABA Bersih Usaha

KOREKSI FISKAL POSITIF

- Biaya Yang Dikeluarkan Untuk Memperoleh

Pendapatan Yang Dikenakan PPH Final

- Biaya PPh 23

- Biaya PP 46

- Biaya Pajak Lainnya

- Harga Pokok Pendapatan yang dikenakan PPh

Final

16.099.378

13.138 .389

24.803.900

$\underline{483.982 .500}$

\section{KOREKSI FISKAL NEGATIF}

Pendapatan Yang Telah Dikenakan PPH Final

TOTAL KOREKSI FISKAL NEGATIF

Penghasilan Kena Pajak 
Berdasarkan Tabel 3 diatas, perusahaan PT. ABC memiliki penghasilan bruto selama satu tahun dibawah 4,8 milyar rupiah $(<4,8 \mathrm{M})$ dan perusahaan menggunakan Peraturan Pemerintah Nomor 46 Tahun 2013 selama tahun pajak 2015.

$$
\begin{gathered}
\text { Pajak Terhutang }=\text { Omzet } \times 1 \% \\
\text { Pajak Terhutang = Rp. } 1.313 .838 .893 \times 1 \% \\
\text { Pajak Terhutang }=\text { Rp. } 13.138 .389
\end{gathered}
$$

Dari perhitungan diatas, berdasarkan Peraturan Pemerintah Nomor 46 dalam menghitung pajak terhutang dengan omzet dikali 1 persen maka besarnya pajak terhutang untuk PT.ABC Tahun pajak 2015 adalah sebesar Rp 13.138.389,00.

Tabel 4. PTABC
LAPORAN LABA (RUGI) SERTA PERHITUNGAN PPH TERHUTANG BERDASARKAN PAJAK PENGHASILAN PASAL 31E
TAHUN 2015




\section{HARGA POKOK PENDAPATAN}

Persediaan Awal

Pembelian

54.042 .500

Persediaan Untuk Dijual

537.425 .000

Persediaan Akhir

591.467 .500

Total Harga Pokok Penjualan

(107.488.000)

LABA (RUGI) KOTOR

483.982 .500

829.856 .393

BEBAN USAHA

Biaya Gaji Karyawan

Biasa Listrik

283.500 .000

3.600 .000

1.767 .500

Biaya Telepon dan Internet

1.833 .677

87.629 .100

Biaya Transportasi

107.881 .800

Umum Kantor

22.187 .500

83.399 .600

Biaya Keperluan Kantor

112.891 .400

Biaya PPh 23

Biaya PP 46

Total Beban Usaha

16.099 .378

$\underline{13.138 .389}$

$\underline{(733.928 .344)}$

Laba Usaha

PENDAPATAN \& BEBAN LAINNYA

Biaya Pajak

Total Pendapatan dan Beban

Lainnya

24.803 .900

LABA Bersih Sebelum Pajak

24.803 .900

71.124 .149

KOREKSI FISKAL POSITIF

- Biaya PPh 23

- Biaya PP 46

- Biaya Pajak Lainnya

TOTAL KOREKSI FISKAL POSITIF

16.099 .378

13.138.389

24.803 .900

KOREKSI FISKAL NEGATIF

54.041 .667

TOTAL KOREKSI FISKAL NEGATIF

Laba Setelah Koreksi Fiskal 
Berdasarkan Tabel 4diatas, perusahaan tidak menggunakan perhitungan pajak penghasilan berdasarkan Peraturan Pemerintah Nomor 46 Tahun 2013, dan menghasilkan laba setelah koreksi fiskal sebesar Rp 125.165.816,00

Perhitungan Pajak Penghasilan Pasal 31E PT.ABC

$$
50 \% \text { x } 25 \% \text { x Rp. } 125.165 .000,00=\text { Rp. } 15.645 .625,00
$$

Perbandingan Beban Pajak Terhutang PP 46 dan Pasal 31E Tahun Pajak 2015

\begin{tabular}{lc}
\hline \multicolumn{1}{c}{ Dasar Perhitungan } & Jumlah \\
\hline Peraturan Pemerintah Nomor 46 & Rp. 13.138.389,00 \\
Pajak Penghasilan Pasal 31E & Rp. 15.645.625,00 \\
\hline
\end{tabular}

Berdasarkan perhitungan diatas dapat diketahui bahwa besarnya pajak yang diterapkan dengan menggunakan Peraturan Pemerintah No. 46 akan memberikan dampak yang menguntungkan bagi pemilik karena memiliki beban pajak penghasilanyang lebih kecil apabila dibandingkan menurut perhitungan Pajak Penghasilan Pasal 31E Nomor 36 UU PPh tahun 2008.

\section{PENUTUP}

Simpulan. Berdasarkan analisis dan pembahasan di atas, perhitungan beban pajak penghasilan terhutang untuk PT. ABC untuk tahun pajak 2014 dan 2015 dengan membandingkan perhitungan beban pajak penghasilan apabila menggunakan Pasal 31E Nomor 36 UU PPh Tahun 2008 dengan Peraturan Pemerintah Nomor 46 tahun 2013 dapat ditarik kesimpulan bahwa Peraturan Pemerintah Nomor 46 tahun 2013 yang diterbitkan oleh pemerintah lebih menguntungkan bagi PT. ABC, karena: (1) Untuk tahun pajak 2014, apabila menggunakan perhitungan dengan Pasal 31E UU PPh akan didapat beban pajak penghasilan terhutang sebesar Rp 12.446.750,00. Dan apabila menggunakan perhitungan menurut Peraturan Pemerintah nomor 46 akan didapat beban pajak penghasilan sebesar Rp 8.594.894,00;(2) Untuk tahun pajak 2015, apabila menggunakan perhitungan dengan Pasal 31E UU PPh akan didapat beban pajak penghasilan terhutang Rp 15.645.625,00. Dan apabila menggunakan perhitungan menurut Peraturan Pemerintah nomor 46 akan didapat beban pajak penghasilan sebesar Rp13.138.389,00.

\section{DAFTAR RUJUKAN}

Anjarwati, Ratna. (2014) PPh Final 1\% Untuk UMKM.Yogyakarta: Pustaka Baru Press.

Kementrian Keuangan Republik Indonesia.(2011) Undang-Undang Nomor 36 Tahun 2008 tentang Pajak Penghasilan. Jakarta: Kementrian KeuanganRepublik Indonesia

Pajak.go.id. (2012) Istilah-Istilah Perpajakan. Diambil dari: http://www.pajak.go.id/content/seri-kup-istilah-istilah-perpajakan.

Peraturan Pemerintah Republik Indonesia Nomor 46 tahun 2013tentang Pajak Penghasilan yang diterima atau diperoleh Wajib Pajak yang memiliki Peredaran Bruto Tertentu

Peraturan Menteri Keuangan Republik Indonesia Nomor 107/PMK.011/2013 tentang Tata Cara Penghitungan, Penyetoran, dan Pelaporan Pajak Penghsilan atas Penghasilan 
dari Usaha yang diterima atau diperoleh Wajib Pajak yang memiliki Peredaran Bruto Tertentu.

Resmi, Siti. (2014) Perpajakan: Teori dan Kasus. Edisi Delapan. Buku Satu. Jakarta: Salemba Empat.

Syahdan, Anuar Saiful dan Rani, Parama Asfida.(2013) Dimensi Keadilan Atas Pemberlakuan PP 46 No. 46 Tahun 2013 Dan Peningkatan Kepatuhan Wajib Pajak.

Surat Edaran Direktur Jenderal Pajak Nomor SE 42/PJ/2013 tentang Pelaksanaan

Peraturan Pemerintah Nomor 46 tahun 2013 tentang Pajak Penghasilan atas Penghasilan dari usaha yang diterima atau diperoleh Wajib Pajak yang memiliki Peredaran Bruto Tertentu www.ortax.org 